\title{
NEW RETAIL MODELS IN ONLINE AND OFFLINE SPACE
}

\author{
Tamás T. SIKOSa , Tamás KOZÁK ${ }^{b}$, András KOVÁCS ${ }^{b}$ \\ ${ }^{a}$ National University of Public Service, 1083 Budapest, Ludovika square 2., sikos.t.tamas@uni-nke.hu \\ ${ }^{\mathrm{b}}$ Budapest Business School, 1054 Budapest, Alkotmány street 9-11., kozak.tamas@uni-bge.hu; \\ kovacs.andras2@uni-bge.hu
}

Cite this article: Sikos T. T., Kozák T., Kovács, A. (2019). New Retail Models in Online and Offline Space. Deturope. 11(3), 9-28.

\begin{abstract}
Our paper focuses on spatial and strategic questions in the field of retailing; thus, we approach the novel trends of retail trade from two directions: regional science approach and retail management/marketing consideration will be applied.

In the first part of the paper space-related retail problems will be introduced. The "retail landscape" has dramatically changed in the last 2-3 decades. Here we will focus on new spaces and omnichannel marketing models. In this part the interrelations between spaces and retailing will be put in the focus.

In the second part, built on the key findings of the previous chapter, we give an overview on space and disruptive technology influenced business models: we point out, how "spatial revolution" lead to changes in distribution, customer behavior, site optimization, and finally cause transformations in strategies of retailers.

In the third part - after giving an overview on new spatial trends and models - we focus on new distributional and robot technology-related spatial questions in retail trade, that we call here "smart retailing".

In the paper more important characteristics and changes of the "retail-space problem set" are highlighted and discussed. The article may contribute to a deeper understanding of spatial business and technology influenced strategies in the field of retail trade.
\end{abstract}

Keywords: space, strategy, retail, smart retailing

\section{INTRODUCTION}

For organizations - based on the traditional approach - the external business environmental factors include for example the government and other legislation, the macroeconomic trends and the changes in social structures. The fourth industrial revolution produced so-called disruptive technological changes affecting on environmental stresses that determine the operation of most of the companies (Schwab, 2017). The disruptive corporate factors basically include such internet-based technologies that are not just fundamentally altering the traditional business models but creating new markets too (cyberspace). These effects cannot be neglected because they require new approaches and methods from business planning to management control. In the case of a trade company the data and information related to the sold product, and the appearance of new distribution channels get bigger and bigger role in value creation, and in 
customer decisions the quickness and transparency, and the increased amount of available options are the most appreciated.

In the case of a trade company a geographically more or less distinct catchment area served as the most important dimension of customer segmentation even 5-10 years ago. The omnichannel distribution channel model requires another kind of stakeholder management. The internet created the category of so-called trait-based community (Ismail, 2014). The geographical proximity is being revaluated, the customers are in the "cloud", communicating in a virtual community (Nagy, 2017). Consequently, reaching the potential customers, understanding and serving their needs require new approach to space and market, new methods and algorithms.

The goal of our study, considering the above mentioned fundamental changes of the market, to show those changes of analysis, strategy, technology and approach to space that result in success for a trade company among the altered market circumstances in the third decade of the 21 st century. During our research we relied on the domestic and international literature as well as on the results of our previous researches. In our present study we focus on presenting the changes in the market(spaces), and on the effects of these changes on the strategical and technological solutions.

In our study we map the paradigm shifts influencing the spatial thinking and operation of corporate management due to the rise of disruptive technologies. The mostly technology-driven change in production models altering the business models of companies fundamentally is called disruptive - that is, destructive and creative in the same time - innovation.

Today most of the retail companies can be characterized by a strongly planning-driven way of thinking and style of management fundamentally based on the current processes. This arose from the strong concentration of the industry - typically in the last 20-25 years - that frequently limited or slowed the market entry and development of small sized businesses. However, the new shapes and channels of retail trade gradually demand the management greater flexibility, faster adaptation and continuous analyzation of the markets. In this study we summarize these challenges to help the members of this industry to ask the right questions, to build proper business models, and to understand better the changing term of spatiality.

\section{NEW SPACES AND MARKETS IN RETAIL TRADE}

Before we address the changes in retail business models and the related business practices and technological solutions, it is important to explain the (r)evolution of the features of the markets 
determining the business processes. In our theoretical conceptualization several different spaceapproaches will be introduced deliberately (positivist and relationist considerations too) because - in our view - to achieve successful retail strategies, diverse space-approaches are needed. Besides classic physical space approaches, network-like spaces and subjective spacenarratives must also be considered.

The above mentioned technological changes, the economic, social and technological processes of globalization placed the concept and domains of market in radically new context. The concept of market in economics was always somehow abstract (Dusek, 2013), but by today- due to the technological revolution - it became more detached from geographical spaces on the one hand, and it became much more a part of it on the other hand.

Good examples of the "relative spatial independence" of retail trade are the global online retailers making their selection available almost worldwide (e.g.: Wish, AliExpress, eBay, etc.). Good examples of spatial dependence are business solutions that communicate, attract and keep customers by geolocation as an important point of their business and marketing strategy. Today a lot of retailers use in-store customer location solutions that are also important tools for improved customer experience.

Based on these it is important to clarify the concept of space and the features of spatiality, because this constitutes the framework of the potentially successful retailer strategy.

Following the train of thoughts of József Nemes Nagy (Nemes Nagy, 2009), space can be organized into five categories which are presented, characterized and illustrated by visual and possibly retail-related examples. From the more tangible and material to the more abstract levels these five categories are as follows:

1. Outer spaces (absolutist, "container-like" space)

2. Inner spaces (relationist, contact space)

3. Sensed and experienced spaces (constructivist approach to space, with subjective spatial perception)

4. Virtual spaces (online space structures, networks)

5. Hybrid spaces

The evolution of the concept and possible interpretations of space had come a long was till today. As József Benedek points out in his considerable summarizing essay, the concept of absolutist ("container-like") space and the concept of relationist ("structured" by the relationships of things existing side by side) was already present in the 16th century and evolving to date (Benedek, 2002). The theory of subjective spatial perception and interpretations is much younger, appeared only in the 70 s years of the last century. The research 
on virtual spaces is only as old as the more widespread access to the internet (starts from the 90s) (Fuchs, 2014).

In outer spaces, namely in the geographical space sensed and well known by us we can observe and describe the spatial processes and structures of various social and economic events. These spatial events have several business and marketing aspects on the level of the inner operation of the companies as well as in micro and macro environment of the companies.

The companies basically operate in the geographical (physical) space, so the geographical spread of the store network (in the case of the traditional "brick and mortar" stores), the geographical spread of the income, the location of the customers - for example by residence or workplace -, etc. are all information with a dimension of space connected to the inner operation of the companies, and so they can be analyzed by spatial aspects.

Most of the micro and macro environmental factors influencing the operation and business success of the companies have important spatial relations, thus they also have a potential to be analyzed by location. The geographical location (vicinity) of the competitors, business partners and customers has crucial importance regarding the success of a company. Too much or too few competitors in the vicinity, or insufficient local demand generated by customers may seriously endanger the profit goals of a company. Like the micro environmental factors, then certain spatial aspects of the macro environmental background may have serious influence on the business success. In addition to several other factors the spatial features of the demographical processes (e.g.: the direction of the movement of population), the differences in the income level of the residents (e.g.: there are "richer" and "poorer" districts of a city), the spatial separation of the economic growth (compare the development of Budapest and Northwestern Transdanubia with the economic backwardness of other regions), and the features of the settlements (e.g.: tiny hamlets in Southern Baranya compared with the towns of the Great Plain) all have significant spatial influences. To understand the environmental factors of a company better the above mentioned and other economic and social events are required to be analyzed and evaluated also by the aspect of spatiality. The methodological characteristics of this are discussed later in details.

The examination of inner or network spaces follows. While we talked about "container-like" space in the case of outer (geographical) spaces with examined things taking defined (describable by coordinates) places, the inner spaces are much more about relationships and interactions than about actual geographical locations.

The inner spaces take form in various contact networks between persons or companies in which the existence, strength/weakness, direction/disorientation of the relationships are more 
determinant then the actual "geographical location" where these relationships take place. In the inner spaces the topology of the contact networks (the amount, spread and degree of hubs, the amount of contacts, and the distance of the participants) is dominant. These spaces of relationships and their aspects can be analyzed mathematically (e.g.: by graph theory models). In trade strategy these relationship spaces can be analyzed for the value chains of trade companies and their suppliers or for the seller-consumer networks as well as for the relationship between an opinion leader or influencer and the customers in company marketing communication (see for example the online communication of Spar and the significance of influencers like Nóra Ördög and Tamás Trunk).

Outer and inner spaces can be considered as objective things the features of thereof are independent of the observer. By contrast, the regional scientific (Faragó, 2013) or sociological (Berger, 2013) approach to the postmodern concept of space can be grasped as the existence of "constructed" spaces that are dependent of the observer. So, there is not just "one space" but several interpretations of space depending on the observer, and the members of a society are not just sensing space but actively contributing to its "creation". This means that in different ages and societies, people create institutions - which is the structuration with the word of Giddens -, resulting in the creation and shaping of the relationships they live in. This process takes place in space, and not in just the "outer" space and time but in our "constructed" space as well. So, we contribute to the creation, sustenance and termination of spaces: the space influences us, and we have influence on the space too. The examination of meeting nodes, daily (traveling) routines, segmentation of activities in time and space, and accessibility of various social groups is an important starting point not just for sociology but for business sciences (marketing) too. In trade, the concept of subjective spaces is a good explanation for the individual courses of the customers inside the stores and supermarkets. These mental space models are responding to the individual interests and interpretations, and determining what paths a customer moves on in a supermarket, how much time they spend there and what they remember from their visit. In the Hungarian literature, while studying environmental psychology in supermarkets Dúll and his co-author pointed out that the inner spaces are sensed and used subjectively. They described the spaces of supermarkets as "strictly regulated common space", "regulated freedom", “controlled coziness", etc. (Dúll \& Demetrovics, 2009), sketching the varied and person-related use of these large area marketing centers.

These studies on subjective space concepts and interpretations point out that for a trade and service provider company the important things are not just the objective location and appearance (size, location) of space itself (as sales area, public space, etc.) but the subjective 
experience of space as well, because they can help or limit the marketing and sales, thereby also the business success of the company.

The variety of virtual (cyber) spaces is not just defined by the amount of virtual spaces where we may express ourselves (by browsing, blogging, using social media...) but also by the different "virtual level" of these spaces, and there are several distinguishable steps between reality (physical space) and total virtuality (conceptual spaces) (Ákos, 2007):

a. Real space

b. Network space

c. Web space

d. Virtual world(s)

While real space means the three-dimensional world around us, the network space is a network created by information systems (network cables, servers, users, etc.), that is the infrastructure of Internet. This space is located in the geographical space but it is operated by its own network rules.

Web space means the various webpages, blogs, community sites and other contents, including the space of hyperlink-based connections between us. This has its own contact network infrastructure.

The virtual worlds are programmed "3D realities" with the main purpose of projecting real space or its elements by information technology. Its goals include entertainment, modelling, planning, marketing, etc.

It is important to see that each interpretation of the virtual spaces has more or less strong contact with the geographical (physical) space (Mészáros, 2003; Kovács 2013). Networks are mapped in geographical space, so web space contents and the users themselves can be found in the geographical space, and their habitat in geographical space (where they connect to the web space) at least partially influences their behavior on the web. There are real users behind the avatars in various virtual worlds, there are real geographical spaces behind the themes of virtual worlds, and there are well-articulated needs of real people behind the dedicated 3D software. Though Second Life and other mainly public-targeted virtual realities (There, Active Worlds) are solutions with limited business success (especially compared to the social media tech companies), unbelievably big perspectives opened for the business use of $3 \mathrm{D}$ realities in the last two decades. The various three-dimensional urban planning and simulation software (for regulating traffic, emergency response goals, modeling wind-flow, etc.), 3D CAD and CAM software for design and production, medical software and 3D military applications are all opening new horizons in the work on several fields. Today, the marketing and trade application 
of these software has significant effect on company strategy. Product visualization based on virtual realities may greatly increase the sales, especially in the case of valuable (e.g.: cars) and multi-component (e.g.: furnishing, bathroom and kitchen design) products. In these areas the car dealers, bathroom tile and sanitary traders, furnishing enterprises use virtual reality software to support (ease) the purchasing choices made by the customers. A car, a fully furnished living room or bathroom simulated in virtual space can be "walked and viewed" before the customer makes their choice to decrease the customer's uncertainty and increase the efficacy of the sales work of the company. For example, building an apartment in $3 \mathrm{D}$ virtual reality means that during the design it is possible to plan everything to the finest details, and not just the dimensions and arrangement of rooms but the color of the walls, the locations and shapes of furniture, and this greatly supports the sales and marketing communication processes.

And this leads to the question of connections between physical and virtual spaces. As mentioned above in relation with virtual spaces, every virtual space (be it the created environment of Second Life or the digital design of a flat) is in connection with the "real" geographical space, because it takes inspiration from the latter to be a plan of a (sometimes not even existing) house that is realized later. The question is how the virtual and geographical realities are connected, separated and creating spaces with new qualities that include the virtual and geographical dimensions as well?

Ákos wrote about such so-called hybrid spaces by presenting "smart" spaces. These are, for example, smart homes in which the floor, doors and windows, and the digital devices of a flat (as a geographical space) are equipped with sensors that are continuously monitoring their environment, and by sending data into the digital space they are optimizing the parameters of the geographical space, namely the flat (Ákos, 2007, p76). By thinking about this concept of hybrid space we created a process-centered approach. Basically, it means that the hybrid spaces are sui generis existent, and come to being temporarily by the process of one or more repetitive social or economic act when the elements (objects) or sections of this act appear in the cyberspace and/or geographical space.

To use a marketing-related example, an online purchase creates a hybrid space when the buyer gives a geographical location (address) for the delivery of the ordered product. The selection and purchasing of the product happens in digital space, but they deliver it in physical, geographical space, and the whole process includes several connections between the digital and geographical spaces. A cosmetologist may offer services online by contacting their customers (by Facebook and/or email), but service-providing itself happens in geographical space (in the 
shop), while aftersales activity (for example, a customer satisfaction survey) may take place on the Internet again.

Online fresh food trade also creates interesting hybrid spaces. Although geographical distances are generally less significant in online trade, the transportability and shelf life of fresh food causes such surcharges (e.g.: refrigerator trucks) that leads to significant geographical limits - because of this a hybrid space is constructed with strong geographical projection and online connection in the same time. On the webpage of a domestic online food seller, G'Roby we can find a list of (Budapest agglomeration) settlements where G'Roby online offers fresh food delivery service. The 29 settlements targeted by G'Roby are Budapest and its agglomeration, but the service is not continuous geographically (see the example of Gödöllö below). Supposedly the vicinity and time-distance of the selected settlements, the frequency of orders by the local size of the market, and the value of orders by settlement together determined the serviceable area. For example, the population and the aggregated income of the residents of Gödöllő together meant a favorable business opportunity for G'Roby, but the company did not extend this to the nearby settlements (e.g.: Veresegyház, Mogyoród, Kerepes).

A special case of hybrid spaces is the augmented reality (AR) that is various visual, auditory and audio-visual information connected to a point (or area) of the geographical space by software applications running on typically a portable IT-device (smartphone, tablet). Studying the augmented reality is desirable, because there is great business and marketing potential in it. For example, IKEA's mobile AR application gives an opportunity to the users to "install" IKEA furniture virtually into their real home-environment, so they can see how the selected furniture looks like on a given place, what size it has, does its color fit into the environment, etc. By this application IKEA offers an innovative solution for the many decades old problem that in the store most customers cannot precisely evaluate the features of the selected furniture. Customer choice based on inappropriate evaluation can easily lead to dissatisfaction that is unfavorable for both the customer and the company. IKEA decreases this uncertainty by its augmented reality application.

However, the application of augmented reality has innumerable business opportunities including those mentioned below in order to point out the features and adaptability of this software solution:

- Several fashion stores use AR-based solutions to speed up the extended fittings. The core of the technology is a big touch screen (e.g.: Microsoft Surface), a webcam, and an appropriate software. The customers select the clothes they want to try on the touch screen, 
then standing in front of the device the system scans their image and fits the selected clothes on their "mirror image" projected on the screen.

- Some Drogerie Markt stores offer an opportunity to "try" the selected colored lipstick and mascara by an augmented reality application at the L'Oréal decorative cosmetics stand. This is carried out by a webcam and a tablet installed into the stand. Standing in front of the stand the customers select the desirable color on the touch screen of the tablet, then the cam projects their "mirror image" onto the screen with the selected colors on their lips and eyelashes.

- There are numerous other areas where augmented reality can be used: for projecting prices onto the goods in shop windows, for increasing the customer experience, for supporting the movements of the customers in large store units, etc.

- Besides the widespread industrial and B2B applications AR-based solutions appeared in culture too. Some museums increase the experience and help their visitors in orientation by descriptions, photos and videos related to the exhibited articles.

All in all, we can see a new "space revolution" today, in which not just the professionals of spatial sciences but marketing and trade people also required to get to know such new terms and devices as virtual reality, subjective space perception and interpretation, or augmented reality "merging" the geographical and cyber spaces into each other.

Continuing our study, we review and estimate the impact of these phenomena on business strategy. We want to point out here how business strategies are influenced by the more and more complex space-approaches. We will highlight where space-related business strategies can be found in the framework of the company strategy (e. g. logistics, delivery, etc.)

\section{BUSINESS MODELS IN TRADE}

The question arises that what role spatiality gets in a business model and development philosophy adapting to the quickly changing environment, and how much stability it represents in respect of making decisions. In the traditional business model - for example during the preparations for a store opening - the catchment area gave a stable starting point for planning the sales potential. If we test our product or service continuously, and are ready to change our business model based on the feedback from the clients, then spatiality can be a changing factor in occasional re-planning if the geographical location of the operation of the enterprise is important. In the case of a strongly innovation-driven enterprise the clients - in many instances - cannot phrase their needs clearly, so the management emphasizes the testing of value- 
generation related hypotheses instead of the traditional market surveys. This approach applies also to the area segmentation of the customers, because there is no determined catchment area in the long term. Besides the continuous testing the role of traditional research and survey is taken over by algorithms (Salim, 2014), and it is not enough to know where are the clients but it is also important to estimate where they will be, and where will the potential customers come in the future.

Today, lot of sales managers may feel that we are witnesses to changes that are not just modifying the well-known operation models but also fundamentally rewriting the terms of spatiality. There is great fear from online trade, but in the last one or two years, significant players of the traditional sales channel oved toward the so-called omni-channel operation model. Innovation and facing the challenges of technology-based development suppose the existence and improvement of four critical abilities in retail trade: the right product must be delivered to the customer at the right place, in the right time and on the right price (Christensen $\&$ Tedlow, 2000). From these criteria perhaps the definition of the right place is the greatest challenge in this environment influenced by so-called disruptive innovations.

\section{Changing business models}

As a consequence of the digital "revolution" the boundaries between the physical and digital worlds got more and more blurred, and it had radical effects on the operation model of traders too. Although with time business models always changed gradually but such a quick and extensive change was unprecedented, and today there is no entrepreneur who could opt themselves out of the effects. The convergence of such business models as, for example, the mobile "telephony", cloud economy, or the so-called Big Data analytics sped up the pace of the changes. This can be well seen in the example that while in the last century the companies of the Fortune 500 needed averagely 20 years to reach 1 billion dollars' equity market capitalization, for example YouTube needed less than 18 months, and Uber made its business value ten times larger during 2 years (Ismail, 2014).

For some companies, digital reform creates confusion, and they feel like being in a dark room. However, others see unequalled business opportunities in it. The digital development's usefulness for a company, and the required changes in its business model are depend on the company's actual phase of growing (Deloitte, 2017). For companies in a startup phase digitalization gives opportunities for innovative business models, and the introduction of new products and services. For the established enterprises the digitalization may help to strengthen 
the loyalty of its existing customer base, and to get new customers. By digitalization, older businesses may overcome the dangers of the slowing pace of development, and introduce new systems making them more effective. The management's ability to recognize and use the advantages of digitalization can be a strategic resource for the extension of the company's life cycle.

Currently our world witnesses an explosive change of relationships, data and innovations, and while the world of IoT and hyperconnectivity changed the market forces, the sources of advantages and the rules are in fact determined by the customers by requiring personalized, simple and seamless experience at every point of contact (Kozák \& Neszmélyi, 2018).

More and more players use digital community spaces to offer their services, share their experiences and intuition, and for trade as well. This all results in the opening of new communication channels toward the customers, and new ways of the better use of sources appear. To utilize these opportunities, traders need to improve not just the monitoring of the market, the Big Data analytics, and the use of social media, but they have to renew their business in a way to make it compatible with the growing digital world and its customers. These socalled interface applications made a whole new technology to rise, because the communication with the clients and the management of the processes in the company currently happens on integrated, uniform platforms (Palao, Lapierre, \& Ismail, 2018). The integrated data handling, the exceptional growth of information and the appearance of new types of business and market algorithms in company management, market analysis and demand forecasting provided free space for the spread of artificial intelligence. This also results in the replacement of routinelike, repetitive human labor by automatization, as we can see numerous examples in logistics, for example, and the movement of goods within it.

The change and the direction of changes in the elements of business models shown in Fig. 1 are good indications of the complexity of this change in trade. Perhaps the biggest change happened in the communication with the clients. Traditional advertisements are more and more replaced by social media and browser-based solutions. The customers initiate the contact, research and collect data, and - in the trader's point of view - the effectiveness of this activity can be deducted from the so-called conversion rates. The palette of sales promotion and persuasion became exceptionally rich. From simple buying and selling to free use there are several ways of persuading the customer. This is related to the method of getting the price of the purchase, the scale being from instant payment through preorder to free use (freemium). Determining value creation is also more nuanced, because the product or service is identified not just by needs or form of appearance, but there is a new aspect of who takes part in the 
development or content creation. The coordinated delivery of the goods through different sales channels created the concept of omni-channel, in which traditional stores and online platforms form a single selling space (Croll \& Yoskovitz, 2013).

Figure 1 Elements of the E-commerce Business Model

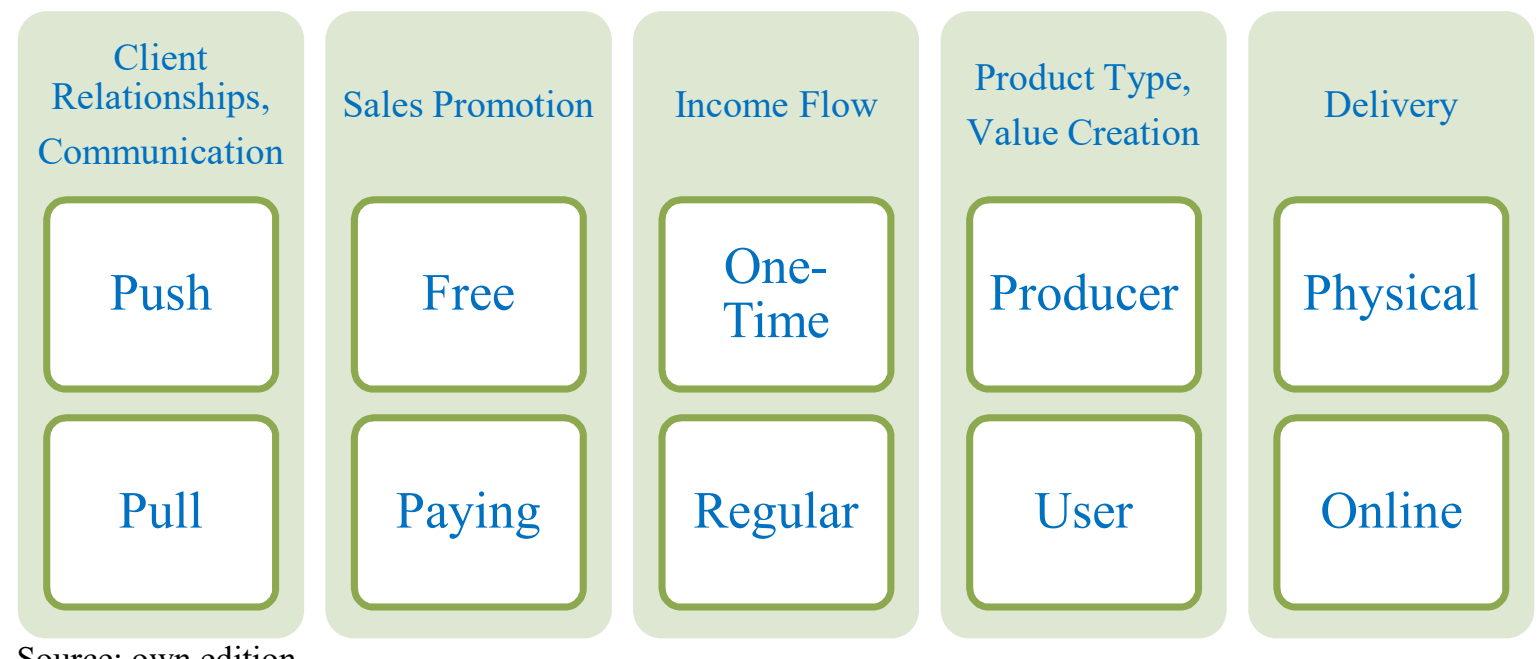

Source: own edition

Companies comfortable in the digital world may compete in the market between more flexible organizational limits, with lesser fixed costs and different customer relationship strategy. The sources of growth moved from the traditional resource-heavy development of infrastructure to the demand-driven market expansion. The concepts of virus marketing, oral tradition and involvement are the new ultimate weapons of marketing strategy creators. Financial planners have to befriend with terms like Click Through Rate and rate of basket abandonment. In the next chapters we describe what this all mean in the daily routine of trade companies comfortable in the digital world. The following, practice-oriented part of our paper will give a short overview on space-related retail business solutions. We will introduce several examples where geographical space, virtual spaces and hybrid spaces (e. g. AR-based solutions) are in use in daily retail operation.

\section{SMART RETAILING}

Retail trade integrates new technological solutions quickly, so it is a good area for linking and networking intelligent systems together. Today costumers have new expectations of retail trade, and this new situation forces both the customer and the seller to rethink the processes of buying and selling - the customer decides how, when, from where and from who they buy, and the seller have to know what, when and where they should offer (Wrigley \& Lowe, 2014). The change in production technology, the spread of pre-packaging, the increase in commercial 
traffic and purchase quantities, the mushroom-like growth of brands and ranges of goods, the widening and deepening of the competition urge trade entrepreneurs to progress together with the new requirements, participate in the sales revolution and create tool systems that are needed for this. The sales revolution arrived to a new phase in the first trimester of the $21^{\text {st }}$ century and it requires more adaptation from the bigger and bigger super- and hypermarkets than the specialty shops and local stores appeared at the dawn of mass production. The new environment of the digital era comes with a paradigm shift not just in the stricto sensu marketing, innovation and trade but in the conditions of the competition too. The key factor of change is the customer (Morrison, 2012) who has interactive devices with no limits of making contacts with anyone who can help or influence their decisions, and the seller is only one possible participant in this. This circumstance makes the market position of entrepreneurs uncertain. In the digital age the customer may require personal service, the freedom of selection makes the customer independent of the producers, and the bigger range of goods with the concentration of specialty shops installed adjacent of each other and the variety of service providers make it possible that shopping becomes pleasure instead of pressure. ${ }^{1}$

Retail trade always reacted quickly to the changes and technological advance of any given age. In the last decade numerous technological innovations appeared in retail trade: barcode readers, QR codes, touch screen information or pricing, radio frequency identification devices (RFID), robots and cellphone applications are more and more widely used. Besides these innovations the financial and economic depression in 2008 forced the companies to change direction. Consequently, stores and supermarkets in traditional space had to move toward eCommerce, and besides the geographical space they started to sell in the cyberspace too. By the ideas of György Enyedi we may say that the future attention of marketing geography should turn toward the contact points of geographical space and cyberspace, so the online and offline world became equally interesting, because sales processes are realized partly in geographical space, and partly in cyberspace. ${ }^{2}$ In the future we shall follow the sales processes happening in the hybrid space.

One of the pioneer users of smart technologies is the retail trade that today has the same significant influence on city development processes as markets, agoras and fairgrounds had in the past when cities emerged from towns. The smart retailing is a part of a wider sense of smart

\footnotetext{
${ }^{1}$ Sikos T. Tamás - Hoffmann Istvánné (2004): A fogyasztás új katedrálisai. Stratégiai Tanulmányok Sorozat, Budapest, MTA Társadalomkutató Központ.

${ }^{2}$ Magánbeszélgetés Enyedi Györggyel. Juszt László’s interview, 10th of October, 2008. MTV2
} 
city concept. By this approach the basic idea is that smart technologies make the quality of life better.

\section{Smart Retailing Technologies}

The dynamically changing retail trade offers numerous opportunities to use modern technology. These new options require the review of the earlier sales system, and enforce the development of such new organizational systems that are able to adapt to the changing conditions of retail trade. These changes affect not just on sales but the customers also must adapt to the new technologies. The world of robotics creates a whole new system of tools and devices for trade. In this system both sides have to relearn the process of purchasing, its dynamics, appearance, locality, operation concepts, online and offline features. Below we would like to present some examples for intelligent tools in retail trade:

- The Czech Alza IT-retailer opened an "unmanned" "Alza Concept Store" in Prague in Flora metro station where shoppers can buy their items $24 / 7$ a week in total privacy ${ }^{3}$.

- In several Hungarian dm (Drogerie Markt) drugstores there are "smart make-up stands" with AR (augmented reality) extension. The shoppers can "try on" the color of lipstick on their lips and make-up colors on their face with the help of a camera and a display.

- Similar face recognition system, for example, helps to keep certain persons away from the trade centers, and gives information on the amount, age and satisfaction of visitors.

- 3D applications are used on a lot of areas. The best known such application is the $i$ CanDesign from IKEA that enables us to furnish our home or office virtually with IKEA furniture by using the data of the geographical space, namely the dimensions of the room in the design process. It ensures the most optimal arrangement of furniture in our home or office, and even a later redesign is much easier this way.

- Tesco in South-Corea introduced "virtual shops" in metro stations where passengers can organize their diary shoppings (Petit de Meurville, Pham, \& Trine, 2015).

- The Style My Hair hairstyle application is also new in 3D design. The artificial intelligence based innovation of L'Oréal Professionnel enables "real-time" hair color changes besides the recognition of hairstyle type by form.

- The use of smart robots is more and more frequent in warehouse systems, for example at Amazon. ${ }^{4}$ These robots make commission more effective because people do not have to go

\footnotetext{
${ }^{3} \mathrm{https}: / /$ m.alzashop.com/alzacz-opens-a-self-service-shop-of-the-future-in-prague (date of download 08/10/2019)

4 Apolcok mennek az emberekhez az Amazon okosraktárában (2014). Source:
} 
for the goods but the robots take the shelves and products to the customers, and this makes the operating of the logistics system more effective. This new system is not just faster and more cost effective but it requires only third of the human workforce that traditional logistics needs, and this significantly increases the market competitiveness of the companies. The BingoBox builds on the "strategic alliance" of Alibaba and Auchan, and "it reflects the future image of $» \mathrm{New}$ Retail «". ${ }^{5}$ Basically, this is an online and offline sales system that operates in a container house under remote control (purchasing, monitoring, inventory management, etc.), and the sales take place in local space (Amazon Go operates with a similar system), human workforce needed only for remote monitoring and restocking. Customers of BingoBox are registered customers with loyalty card used as identification document for entering. They pay through express checkout, and the surveillance is performed by camera systems. This means a costumer may leave the BingoBox only with products they paid for, because in case of theft the camera system alerts the remote supervision and blocks the doors. Using the BingoBox offers a solution for an old site selection question too, because the superstructure can be moved easily, so in case of bad site selection it is suitable for a flexible relocation to a better place.

- "Virtual walls" in metro stations or at any other traffic hub offer significant help for the customers to use their shopping time optimally. Products appearing on the virtual boards can be easily purchased and ordered by a QR (Quick Response) code mobile phone application (e.g.: touch screen apps in Dubai or QR code apps in South Korea). The application enables changes in the quantity of ordered goods, and the customer may pay by cellphone, and gives the shipping address and time electronically. In the background the logistics is done partly by robots, and partly ensured by the traditional delivery system. This new kind of sales strategy helps commuters to use their time effectively.

- Drones offer new opportunities in smart retailing, in the delivery of urgent and sensitive products, and in inventory management. By using drones stock can be counted quickly and easily.

- The technology of 3D printing contains the future opportunity of buying a product and printing it immediately after the purchase.

http://smart.blog.hu/2014/05-

/14/a_polcok_mennek_az_emberekhez_az_amazon_okosraktaraban (date of download: 07/01/2018).

${ }^{5}$ Az Alibaba és az Auchan együtt tarolnak Kínában (2017). Source: www.origo.hu/gazdasag/20171121-azalibabaes-az-auchan-kozos-erovel-hoditja-meg-a-kinai-piacot.html (date of download: 07/01/2018). 
Thus robotisation, especially the use of self-taught robots gains more and more important role in online and offline retail trade. As an evidence to this, robots were the stars of the Consumer Electronics Show (CES) in Las Vegas, 2018. Even earlier the usage of robots was significant for example in logistics, but last year robots can work as shopping assistants in trade centers. Shopping assistant robots (Shopping Cart Robot) are able to read barcodes and tell the customer the exact price of the goods, and even the exact instore location of a good selected in a mobile application by the customer, speeding up the process of shopping, and making it a special experience.

\section{Towards a smart retailing business model}

In smart retailing continuously appearing new cybertechnology makes the regular review of the whole shopping process necessary. In this new system the seller's and the customer's relationship with the process and technology of shopping is changing. (See Fig. 2.)

Figure 2 Elements of Smart Retailing

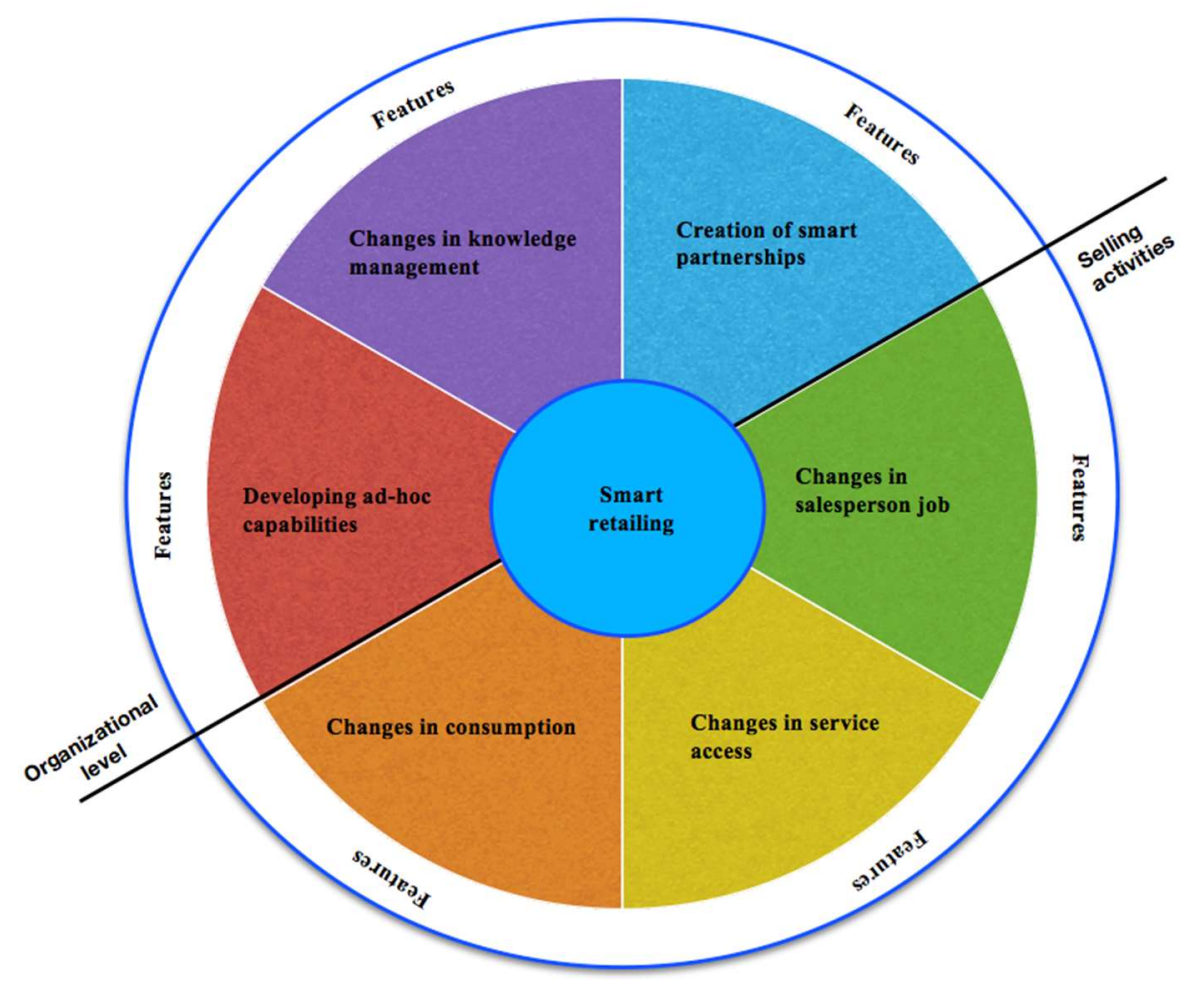

Source: Pantano \& Timmermans, 2014, 104. Consumer Electronics Show; www.cnet.com/ces/ (date of download: 07/01/2018) 
The main elements of smart retailing are: (1) Ability to react quickly on organizational side; (2) changes in Knowledge Management; (3) contact with the smart partners; (4) changes in the work of the seller on the sales side of the company; (5) access to services; (6) changes in consumption. ${ }^{6}$

Companies participating in smart retailing have to monitor the needs of the market continuously and must adapt to these needs quickly, and in the same time they are required to integrate the new technological solutions into their sales system. Meeting this requirement is the basic condition for companies using smart technologies to keep their competitiveness. The ability to react quickly is a must for these companies on organizational level and in technological development alike.

In smart retailing information are continuously exchanged between the companies and the customers. The important questions are: How to relay the updated information to the customers on a given product, and how to collect the customer experience about the products. It must be assessed how to clarify the most valuable information from the existing and growing data bases (Big Data). To solve this successfully we shall pursue the development of an analyzing and filtering system that highlights only the most important information, and for this the expertise of the management handling the process is very important. New technologies in the sales system, for example the utilization of robots requires an entirely new knowledge from the seller, but even the use of shopping assistants (Shopping Cart Robots) affects the shopping process and requires a higher level of expertise from the management. Briefly: intelligent technologies need "smart management".

The companies also have to make their partnerships progressive cooperation. This means that, for example, traditional retail companies shall agree to an alliance with partners already adapted to the technical conditions of eCommerce. The cooperation of Alibaba and Auchan, or the alliance of Walmart and Google are good examples. ${ }^{7}$ In smart retailing the job of the seller also changes, because the seller is expected to have a more multi-faceted knowledge than in the traditional form of retailing. The seller has to know the details of the operation of the new technology, because they can effectively help the customer only by this knowledge. In the same time, it is also a fact that the utilization of new technologies consequently leads to a decreased

\footnotetext{
${ }^{6}$ Based on Pantano és Timmermans. Eleonora Pantano - Harry Timmermans (2014): What is smart for retailing? Procedia Environmental Sciences, Vol. 22. 101-107.

${ }^{7}$ The alliance of Walmart and Google is mainly against Amazon, because they would like to challenge Amazon's market leadership. Google pursued this goal for a time now with its services Google Shopping and Google Express, but it could not achieve being a real competitor to Amazon. Now Google has an opportunity to change this by its partnership with Walmart regarded as a market giant in traditional trade.
} 
need of human workforce, because the sales process becomes more and more robotized (for example, the logistics of Amazon is fully robotized).

The change in purchasing points (geographical space, cyberspace) results in new challenges in the utilization of smart technologies. Traditional trade happens in geographic space while the place of eCommerce is in the virtual space. This new situation not just affects the sales process, but it requires new conditions in the case of certain services, including a wide spectrum of banking services in the virtual space. The new form of sales demands that the services shall fit to the appearance of new technologies, thus the organizations have to develop newer and newer smart service systems, and in the same time sales in the virtual space changes the behavior of both the seller and the customer.

In the smart retailing system both the process and structure of purchasing are changed. The existence of new technologies affects to the buying process, because the customer is not there in the geographical space in the traditional sense - purchasing goods in the cyberspace drastically changes the behavior of the customer and the shopping experience. In the classic purchasing process, the customer seeks, compares, selects and buys the product. In many cases impulse buying prevails, but in the cyberspace purchasing is a more conscious process because the customer is bound by no geographical space or time. Consequently, the new sales system may meet the requirements only if there is a new service network in the background that offers modern services and utilizes robot technology. Thus smart retailing is nothing else than an innovative sales strategy approach and tool system using modern retailing technologies, in which market players are continuously renewing themselves and learning the utilization of new technologies. The world of robotics wholly permeates this new system. In smart retailing the companies' response to the challenges of the market is exceptionally quick, and they cooperate with "smart partners" in order to keep their competitiveness. Thus the customers may benefit from more comfortable shopping experiences.

\section{CONCLUSION}

The aim of our paper was to point out what direct and indirect connections there are between space-narratives and retail company strategies. We wanted to emphasize that effective and efficient retail strategies cannot be elaborated without a complex approach to space that includes all the novel space-interpretations: besides geographical space, virtual and hybrid spaces must be immanent part of retail strategies.

Our conceptual research and the introduced examples underline the importance of spatial thinking in business decisions. Further researches are needed to carry out in the fields of 
theoretical modeling and in practice too. In the near future we aim to create a spatial model on smart retailing strategies, and we plan to conduct empirical researches to underpin this conceptual framework.

\section{REFERENCES}

Ákos, J. (2007). Az információs társadalom térbelisége. Regionális Tudományi Tanulmányok 13. ELTE, Budapest.

Benedek József (2002). A földrajz térszemléletének hullámai. [Waves of space approaches in geography] Tér és Társadalom. 2. szám, 21-39.

Berger, V. (2013). A tér problémája Anthony Giddens társadalomelméletében. [The problem of space in Anthony Gidden's sociological theory] Replika 1. 25-53.

Berta, S. (2017). Együttmüködik a Walmart és a Google. [Walmart and Google cooperate] Source: https://sg.hu/cikkek/ittech/126899/egyuttmukodik-a-walmart-es-a-google (date of download: 07/01/2018).

Christensen, C. M., \& Tedlow, R. S. (2000). Patterns of Disruption in Retailing. Harvard Business Review, 78(1), 42-45.

Croll, A. \& Yoskovitz, B. (2013). Lean Analytic: Use Data to Build a Better Startup Faster, O’Reilly Media.

Deloitte (2017). Disruptions in Retail Through Digital Transformation. https://www2.deloitte.com/content/dam/Deloitte/in/Documents/CIP/in-cip-disruptions-inretail-noexp.pdf (date of download: 27/03/2019).

Dúll, A., \& Demetrovics, Z. (2009). A bevásárlóközpontok környezetpszichológiai ambivalenciái. [Environmental psychological ambivalences of shopping centers] Korunk, 3(12), 39-46.

Dusek, T. (2013). Tér és közgazdaságtan. [Space and economics] L'Harmattan-TIT Kossuth Klub. Budapest.

Faragó, L. (2013). Térelméleti alapvetések konstruktivista ismeretelméleti megközelítésben. [Foundations of space theory in constructivist epistemological approach] Tér és Társadalom, 27(4), 3-29.

Frost \& Sullivan (2013). Strategic Opportunity Analysis of the Global Smart City Market. Retreived from: www.egr.msu.edu/ aesc310-web/resources/SmartCities/Smart\%20City \%20Market\%20Report\%202.pdf (date of download: 07/01/2018).

Fuchs, C. (2014). Social Media and the Public Sphere. In: tripleC 12(1), 57-101.

Kovács, A. (2013). Az e-kereskedelem földrajzi dimenziói Magyarországon. In Tiner, T, Tóth, T. (szerk.). A falutipológiától a marketingföldrajzig. Gödöllő, Szent István Egyetemi Kiadó; 67-82.

Kozák, T., \& Neszmélyi, G. I. (2018). Trendek, trendváltások a kereskedelemben JURA, Pécsi Tudományegyetem Állam- és Jogtudományi Kar, 24; 475.

Mészáros, R. (2003). Kibertér - A földrajzi tudás új dimenziói. Hispánia Kiadó. Szeged.

Morrison, E. (2012). Tales from the Mall. Cargo Publishing 1td. Glasgow.

Nagy, E. (2017). New consumption spaces and cross-border mobilities. In: Derek Hall (ed): Tourism and Geopolitics. Issues and concepts form Eastern and Central Europe. CAB International, Wallingford, UK, pp.142-158.

Nemes Nagy, J. (2009). Terek, helyek, régiók - A regionális tudomány alapjai. Budapest, Akadémiai Kiadó.

Palao, F., Lapierre, M., \& Ismail, S. (2018). Exponential Transformation, Diversion Publishing. Pantano, E. \& Timmermans, H. (2014). What is smart for retailing? Procedia Environmental 
Sciences, 22, 101-107.

Petit de Meurville, M., Pham, K., \& Trine, C. (2015). Shop on the Go. Retrieved from: www.businesstoday.in/magazine/lbs-case-study/case-study-tesco-virtually-creatednewmarket-based-on-country-lifestyle/story/214998.html (date of download: 07/01/2018).

Ismail, S. (2014). Exponential Organizations, Diversion Publishing.

Schwab, K. (2017). The Fourth Industrial Revolution. New York, Crown Business.

Sikos T. T., \& Hoffmann, I. (2004). A fogyasztás új katedrálisai. Stratégiai Tanulmányok Sorozat. Budapest, MTA Társadalomkutató Központ.

Wrigley, N., \& Lowe, M. (2014) Reading Retail: A Geographical Perspective on Retailing and Consumption Spaces. Abingdon and New York: Routledge.

Internet sources:

Az Alibaba és az Auchan együtt tarolnak Kinában [Alibaba and Auchan devastate the market in China together] (2017). Retrieved from: www.origo.hu/gazdasag /20171121-az-alibabaes-az-auchan-kozos-erovel-hoditja-meg-a-kinai-piacot.html (date of download: 07/01/2018).

A polcok mennek az emberekhez az Amazon okosraktárában [Shelves go to humans in the smart warehouse of Amazon] (2014). Retreived from: http://smart.blog.hu/2014/05/14/a_polcok_mennek_az_emberekhez_az_amazon_okosrakt araban (date of download: 07/01/2018).

Consumer Electronics Show. Source: www.cnet.com/ces/ (date of download: 07/01/2018).

Magánbeszélgetés Enyedi Györggyel. Juszt László interjúja, 2008. október 10. MTV2.

RTA opens Smart Mall in four Dubai Metro Stations (2016). Source: www.emirates247.com/news/emirates/rta-opens-smart-mall-in-four-dubai-metro-stations2016-12-17-1.645121 